\title{
Early cytological diagnosis of extranodal stage I, primary thyroid Non-Hodgkin lymphoma in elderly patients. Report of two cases and review of the literature
}

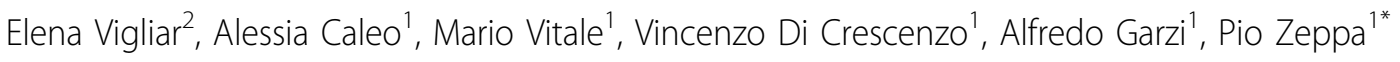 \\ From 26th National Congress of the Italian Society of Geriatric Surgery \\ Naples, Italy. 19-22 June 2013
}

\begin{abstract}
Background: Primary thyroid lymphomas (PTLs) account for 5\% of thyroid malignant tumors and often develop in patients with Hashimoto Thyroiditis (HT). Fine-needle cytology (FNC) is widely used in the diagnosis of thyroid nodules, including those arising in HT. Two PTL cases in HT elderly patients are here described and discussed.

Methods: FNC was performed in rapidly enlarged thyroid nodules of 2 elderly patients under ultrasound (US) control. FNC was used to prepare conventional cytologic smears, immunocytochemistry (ICC) and flow cytometry (FC) assessment of cell populations.

Results: The above cases were diagnosed as well differentiated, small B-cell and diffuse large B-cell thyroid lymphomas, respectively, by means of FNC. The histological diagnoses were mucosa-associated non Hodgkin lymphoma (MALT) and diffuse large B-cell lymphoma (DLBCL), confirming FNC diagnoses, and patients were treated accordingly.
\end{abstract}

Conclusions: FNC diagnosis of PTL is reliable and accurate; it may be conveniently used in the clinical practice since it provides indications for appropriate therapeutic procedures or diagnostic surgery, and avoids to treat benign nodules.

\section{Introduction}

Primary thyroid lymphomas (PTLs) are a rare group of diseases that accounts for $5 \%$ of all thyroid malignant tumors, and approximately for $1 / 2 \%$ of all extra nodal lymphomas. Most PTLs are B- and T-cell non-Hodgkin lymphomas (NHLs), whereas primary thyroid Hodgkin lymphoma (HL) has been occasionally reported [1]. An high percentage of PTLs affects patients suffering from long standing Hashimoto Thyroiditis (HT), therefore PTL pathogenesis is probably related to chronic inflammation stimulation [2]. Although HT mainly affects women and adult patients, men and younger patients

\footnotetext{
* Correspondence: pzeppa@unisa.it

${ }^{1}$ Department of Medicine and Surgery, University of Salerno, Italy Full list of author information is available at the end of the article
}

may also be affected [2-4]. PTL clinical signs include a rapidly enlarging mass in the thyroid area, variable hoarseness and dyspnea. NHL symptoms, such as weight loss, fever and nocturnal sweats, may also be present, although less frequently. Most PTLs are B-cell NHL, being mucosa-associated-lymphoid tissue (MALT) lymphoma and diffuse large B-cell lymphoma (DLBCL) the most frequently reported histotypes [5]. Treatment and prognosis depend on the specific subtype and staging; surgical treatment of localized tumors, radio and chemotherapy for low-grade and high-grade histotypes respectively is generally utilized [6]. A 5-year survival of $90 \%$ has been reported in correctly diagnosed and treated PTL patients [7]; therefore a timely and accurate diagnosis of PTL is mandatory for treatment and prognosis. Palpable neck masses are not a rare occurrence, 
some time representing a challenging diagnostic dilemma with unusual extrathyroidal masses $[8,9]$. Serological or cellular biomarkers would be of great diagnostic utility to distinguish benign from malignant thyroid nodules [10]. For instance, an increase in circulating levels of pro-angiogenic cytokines, as well as of bone marrow-derived endothelial progenitor cells (EPCs), has been observed in tumor patients [11-14]. Unfortunately, calcitonin is the only available biomarker to this purpose, and its utility is limited to the diagnosis of medullary thyroid carcinoma. Both molecular and functional studies have revealed that neoplastic cells remodel their $\mathrm{Ca}^{2+}$ signaling machinery [11,15-18], thereby leading the notion that up-regulated plasmalemmal $\mathrm{Ca}^{2+}$-permeable channels might serve as alternative diagnostic markers of neoplastic transformation [18]. Unfortunately, these studies are yet to be performed in PTL. Fine-needle cytology (FNC) is the primary diagnostic tool [19-24] for all other nodular thyroid diseases. Inconclusive results are frequent and the application of molecular techniques to FNC has dramatically increased its sensitivity [24-32], including in HT cases with diffuse or nodular enlargement [31]. These advantages are enhanced in case of HT, which does not require surgical treatment, and even more in elderly patients, for whom surgery is generally more burdensome, complex and expensive than younger patients [33]. The aim of this study is to present 2 cases of PTL in elderly patients in which FNC pre-surgical diagnosis has contributed to a correct and differentiated treatment.

\section{Materials and methods}

Between January 2010 and December 2012, 1.256 patients with thyroid nodules or diffuse swelling underwent FNC in the outpatient clinics of the Azienda Ospedaliera Universitaria, University of Salerno. Two of these patients were diagnosed with PTL; the first patient was a 66-year-old man who suffered from long standing HT. The gland had progressively enlarged in the last months causing dyspnea and difficulty in swallowing. The second was a 68-year-old woman with an undefined history of long standing goiter, who complained dyspnea, voice change and choking. Both patients underwent ultrasound (US)-guided FNC with rapid on-site evaluation (ROSE), as previously described [34-36]. The diagnostic procedure and its related risks were first discussed with the patients, who were also informed that 1 or 2 supplementary passes might have been needed, and an informed consent was obtained. Additional passes were used to prepare additional smears for immunocytochemistry (ICC) and cell suspensions in buffer solution to perform flow cytometry (FC) assessment of the cell populations. Monoclonal antibodies used for ICC were directed against thyroglobulin (TG), leucocyte common antigen (LCA), cytokeratin (CK), CD20, CD3, CD4, CD8, CD5, CD10, CD19, kappa and lambda light chains. Fluoresceinated antibodies for FC were: basic combinations of phycoerythrin (PE), perdin chlorophyll protein (PERCP) and fluorescein isothiocyanate (FITC) antibodies. Antibodies were purchased from Becton Dickinson (San José, CA). Antibodies clones, dilutions and technical details for both procedures were previously described $[37,38]$. In particular, FC data were interpreted accordingly in this specific clinical and anatomical setting $[32,39]$; with regard to the light chain evaluation for clonal assessment of the lymphoid cell populations, a percentage of the gated cells showing $\kappa / \lambda$ unbalance $\leq 20 \%$ of the gated cells was considered evidence of clonality [32]. FC and ICC assessments were used to perform the final diagnoses and were included in the cytological reports.

\section{Results}

Case 1: At the time of FNC, US evaluation showed diffuse homogeneous enlargement of the right thyroid lobe, that measured $60 \mathrm{~mm}$ in diameter. The edges were smooth and the gland showed a homogeneous isoechoic pattern; FNC showed a dispersed population of immature medium size (Figure 1) lymphoid cells and small mature lymphocytes intermingled among the main cell population. Immature large lymphoid cells were roundish, 2 times the size of the mature lymphocyte and showed granular chromatin, nuclear membrane irregularities and 1 or 2 evident nucleoli. No thyroid follicular cells were observed. ICC showed LCA- and CD20-positivity in the main large cell population, CD3-positivity in small lymphocytes, and negativity for thyroglobulin. FC assessment of gated lymphocytes showed a large proportion of B-lymphocytes, identified by CD19. T-lymphocytes, identified by $\mathrm{CD} 5, \mathrm{CD} 4$ and $\mathrm{CD} 8$, were also present. $\mathrm{B}$-lymphocytes were CD10-negative and showed $\mathrm{k}$ light chain restriction in $40 \%$ of the cell population (Figure 2). The differential diagnosis between PTL and HT with severe lymphoid infiltrate was taken into account. Nonetheless, HT was excluded because it generally shows lymphoid cells of variable size, plasma cells and tingible body macrophages, which were absent in this case. Moreover, the above reported $\mathrm{k}$-light chain restriction was considered diagnostic for a B-cell type PTL arisen in HT. The patient received combination chemotherapy (CHOP) with local radiotherapy without surgical treatment; he is alive and free from signs of disease, to date.

Case 2: US showed an ill-defined, hypoechoic mass that, starting from the left thyroid lobe, infiltrated the surrounding neck structures including the sternocleidomastoid muscle. FNC showed an immature and dispersed large cell population. Cells showed evident nuclear abnormalities, coarse chromatin and 1 or 


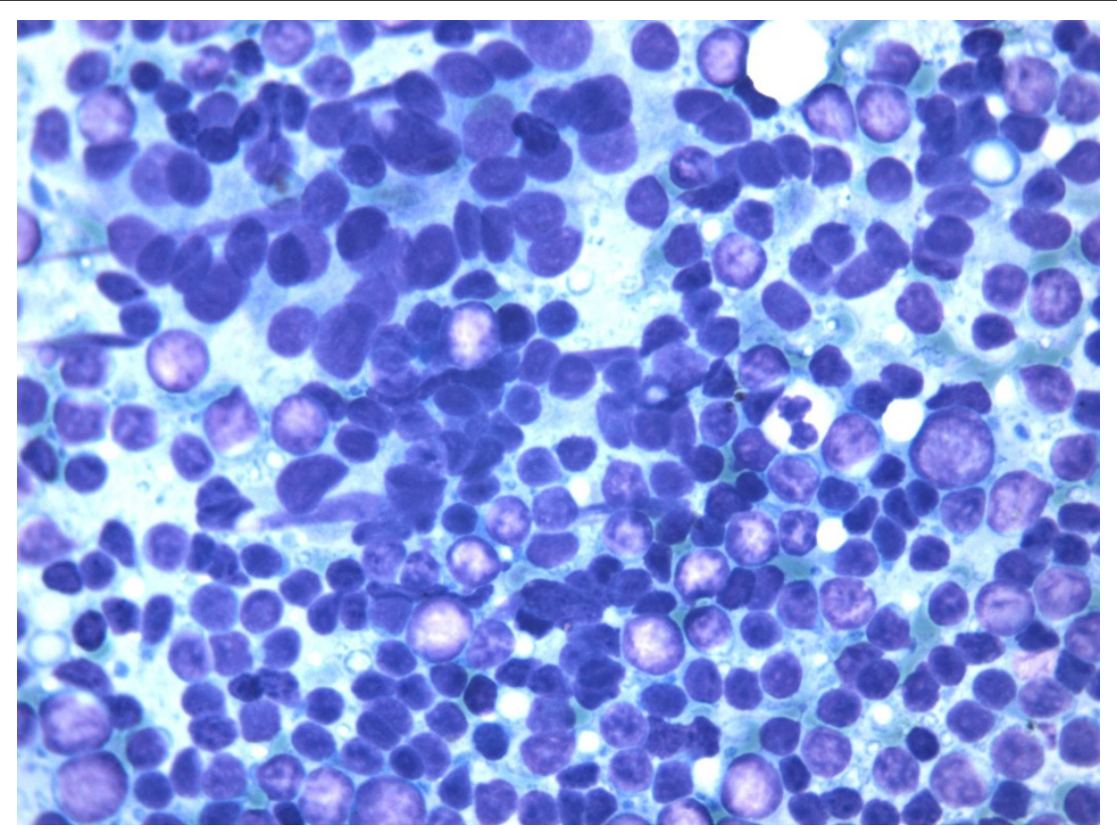

Figure 1 Case 1 FNC smear showing monomorphic population of atypical lymphoid cells. Thyroid follicular cells are absent. (Diff Quik stain 430X).

2 evident nucleoli (Figure 3). Scattered mature lymphocytes were present in the background, and no thyroid follicular cells were observed. ICC showed positivity for LCA, CD20 and for CD3 in small lymphocytes, being the main large cell population, and negativity for thyroglobulin. FC assessment of gated lymphocytes showed the large cells to be B-lymphocytes, identified by CD19. T-lymphocytes, identified by CD5, CD4 and CD8, were also present. B-lymphocytes were CD10-negative; light

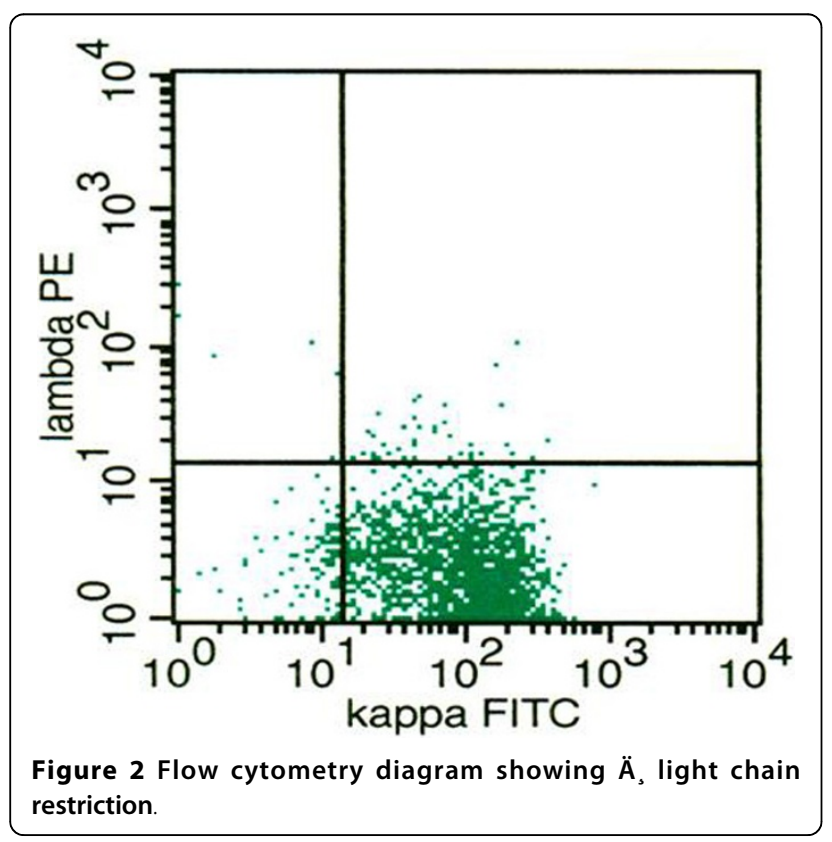

chains were not expressed. Because of the clinical presentation and the cytological features, a differential diagnosis of a possible anaplastic carcinoma was pointed out. Nonetheless, this possibility was excluded as ICC and FC data assessed the lymphoid B-cell origin of the neoplastic cells and FC did not detect light chain restriction. Therefore a cytological diagnosis of large B-cell NHL was pointed out. Notwithstanding the US and clinical presentation, lobectomy was performed and the following histopathological analysis confirmed the cytological diagnosis of NHL, which was morphologically and immunohistochemically consistent with diffuse large B-cell non-Hodgkin lymphoma (Figure 4). The patient received combination chemotherapy (CHOP) with local radiotherapy; she is alive and residual disease was detected at the last follow-up.

\section{Discussion}

Primary thyroid lymphoma (PTL) is a lymphomatous process which develops in the thyroid without involvement of primary lymphoid organs or distant metastases at diagnosis [40]. As reported above, PTL mostly arises in the setting of autoimmune thyroiditis and takes an average of 20 to 30 years to develop after the onset of lymphocytic thyroiditis [41]. PTL frequently presents in IE/IIE clinical stages, with some clinical and imaging problems. A short history of a rapidly enlarging neck mass, often associated with dyspnea, difficulty in swallowing, or voice change, is the hallmark presentation of thyroid lymphoma [42]. These signs, as well as imaging procedures, may overlap with those of other benign and 


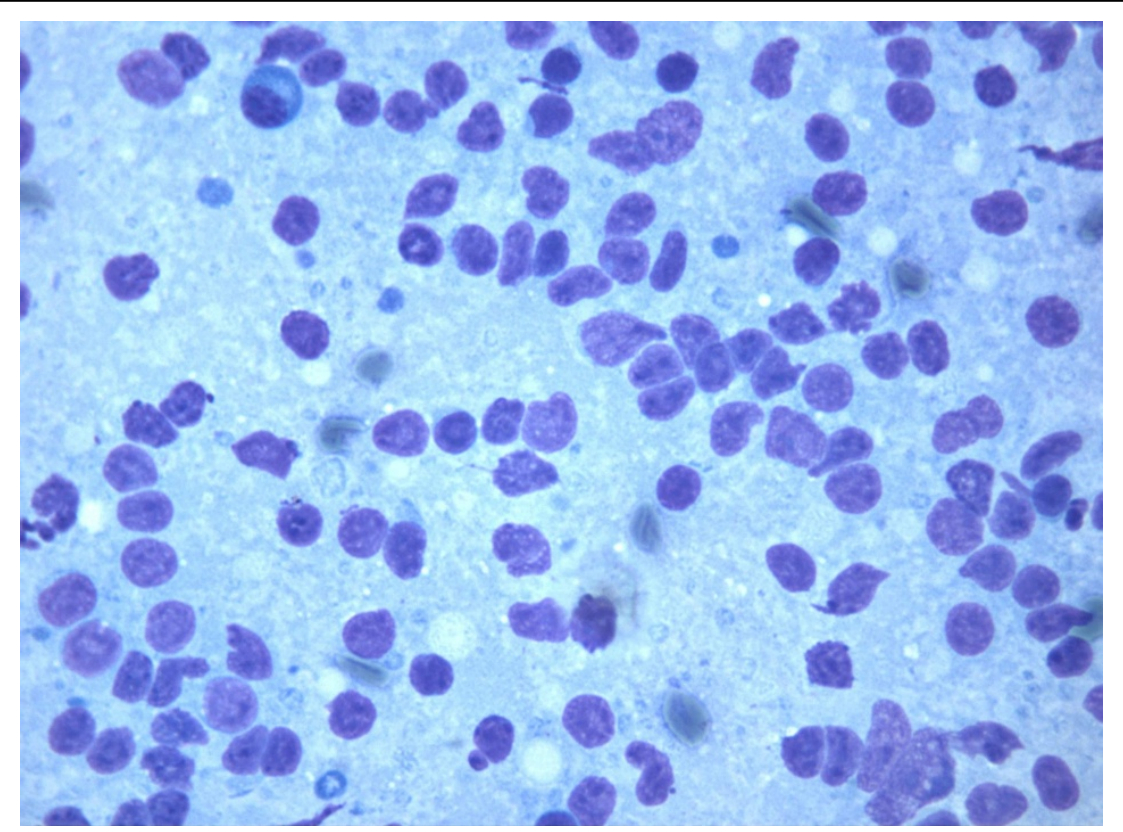

Figure 3 Case 2 FNC smear showing atypical large lymphoid cells in a necrotic background (Diff Quik stain 430X)

malignant thyroid pathologies and require an accurate pre-surgical diagnosis. FNC is the most frequently used procedure for the initial pathological diagnosis of thyroid nodules [43]. Conventional examination of cytologic smears yields inconclusive results that can be refined by testing for specific genetic alterations $[26,27,44,45]$. FNC has the highest levels of sensitivity and specificity [43], but studies have shown inconsistent results in the diagnosis of PTL. A correct diagnosis of PTL with FNC was made in $70 / 80 \%$ of cases [46], whereas other studies report that FNC was suggestive but not diagnostic in only $50 / 60 \%$ of cases $[47,48]$. The 2 study cases were

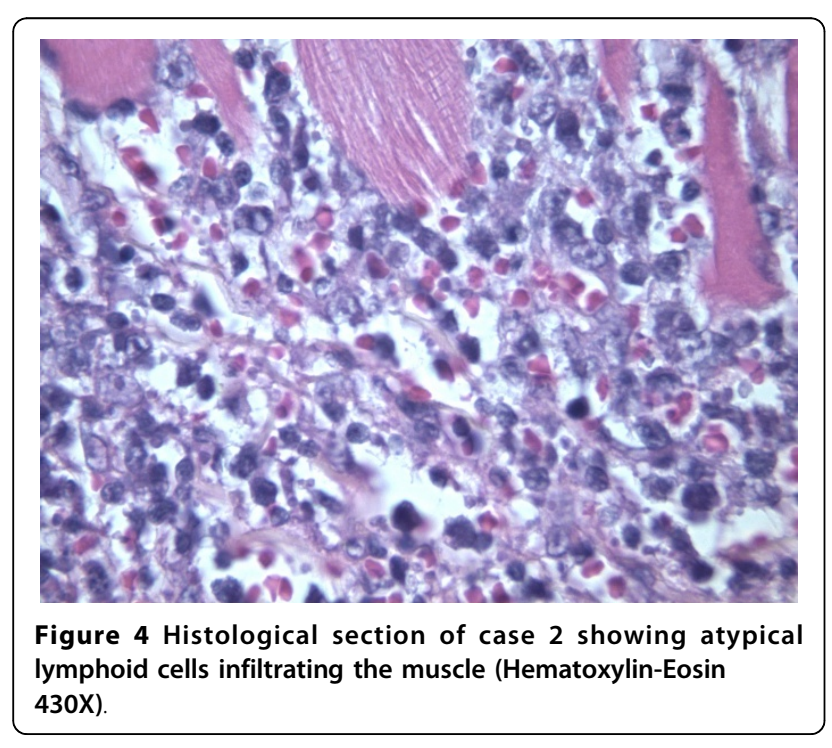

both correctly diagnosed and are an example of the 2 main occurring histotypes, the cytological diagnostic difficulties and the importance of ancillary techniques applied to FNC. As reported above, in the first case the main differential diagnosis of HT with severe lymphoid infiltrate was pointed out. Indeed, the US presentation of HT is quite variable, ranging from normal thyroid parenchyma imaging to diffuse homogeneus enlargement or atrophy, up to uninodular or multinodular presentation in $+/-50 \%$ of cases $[49,50]$. The US appearance of the nodules is also extremely variable; nodules may be hypo or hyper echoic, can have calcifications (micro and scattered, macro or eggshell calcifications), and may also show a hypoechoic halo. The cytological presentation showed the prevalence of lymphoid cells, which gave smears a lymph node-like appearance, including the prevalence of immature follicular centre cells. Finally, the possible presence of small clones of B cells with light chain restriction has been reported in HT, adding further diagnostic difficulties. On the other side, the monotonous cytological smear of immature lymphoid cells, the lack of thyroid follicular cells and the presence of large chain restrictions in most FC assessments of $\mathrm{T}$ gated cells strongly supported the diagnosis of PTL. In the second case, other diagnostic difficulties were encountered; in fact, clinical presentation and cytological features clearly indicated a malignant tumor, but a differential diagnosis of possible anaplastic carcinoma was pointed out. However, in this case FC did not show light chain expression, as it can occur in high grade B-cell NHL. Nonetheless, ICC and FC clearly indicated 
the lymphoid B-cell origin of the neoplastic cell. Therefore properly used ancillary techniques, together with clinical and imaging data and cytological features, allowed the diagnosis of PTL. This possibility enhances the cytological diagnosis not only in PTL cases, but also in the benign hyperplastic and nodular presentation of HT, in which surgery should not be considered neither for diagnostic or therapeutic purposes. PTL treatment is similar to other nodal NHLs. In case of intermediate or high-grade lymphoma, the best results are obtained with cyclophosphamide, doxorubicin, vincristine and prednisolone (CHOP) based chemotherapy. Radiotherapy is generally used after 3-6 CHOP courses in the form of modified mantle irradiation, including thyroid, bilateral neck, supraclavicular area and mediastinum [4]. Unfavorable prognostic factors include age ( $>60$ years), elevated levels of serum lactate dehydrogenase (LDH) and $\beta_{2}$ microglobulin, extranodal sites involvement and III-IV stage [46]. Our patients received CHOP-based chemotherapy and radiotherapy; both are alive with (case 2) and without (case 1) signs of disease. In conclusion, the cytological diagnosis of PTL is reliable and accurate; it may be conveniently used in the clinical setting since it provides indications for diagnostic surgery, when needed, and avoids to treat HT cases.

\section{Competing interests}

The authors declare that they have no competing interests.

\section{Authors' contributions}

PZ, MV: conception and design, interpretation of data, given final approval of the version to be published; AC, EV, VDS, MV, AG, VDC: acquisition of data, drafting the manuscript, given final approval of the version to be published; PZ, MV: critical revision, given final approval of the version to be published.

\section{Declarations}

Funding for this supplement came from personal funds.

This article has been published as part of BMC Surgery Volume 13 Supplement 2, 2013: Proceedings from the 26th National Congress of the Italian Society of Geriatric Surgery. The full contents of the supplement are available online at http://www.biomedcentral.com/bmcsurg/supplements/13/S2

\section{Authors' details}

${ }^{1}$ Department of Medicine and Surgery, University of Salerno, Italy. ${ }^{2}$ Department of Biomorphological and Functional Sciences, Faculty of Medicine and Surgery, University of Naples "Federico II", Italy.

Published: 8 October 2013

\section{References}

1. Wang SA, Rahemtullah A, Faquin WC, Roepke J, Harris NL, Hasserjian RP: Hodgkin's lymphoma of the thyroid: a clinicopathologic study of five cases and review of the literature. Mod Pathol 2005, 18(12):1577-1584.

2. Derringer GA, Thompson LD, Frommelt RA, Bijwaard KE, Heffess CS, Abbondanzo SL: Malignant lymphoma of the thyroid gland: a clinicopathologic study of 108 cases. Am J Surg Pathol 2000 24(5):623-639.

3. Widder S, Pasieka JL: Primary thyroid lymphomas. Curr Treat Options Oncol 2004, 5(4):307-313.

4. Miller TP, Dahlberg S, Cassady JR, Adelstein DJ, Spier CM, Grogan TM, LeBlanc M, Carlin S, Chase E, Fisher Rl: Chemotherapy alone compared with chemotherapy plus radiotherapy for localized intermediate- and high-grade non-Hodgkin's lymphoma. N Engl J Med 1998, 339(1):21-26.

5. Thieblemont C, Mayer A, Dumontet C, Barbier Y, Callet-Bauchu E, Felman P, Berger F, Ducottet $X$, Martin C, Salles G, et al: Primary thyroid lymphoma is a heterogeneous disease. J Clin Endocrinol Metab 2002, 87(1):105-111.

6. Larsen PR, Ingbar SH: The thyroid gland. Philadelphia: Saunders, W.B.; 81992.

7. Alzouebi M, Goepel JR, Horsman JM, Hancock BW: Primary thyroid lymphoma: the 40 year experience of a UK lymphoma treatment centre. Int J Oncol 2012, 40(6):2075-2080.

8. Soscia A, Guerra G, Cinelli MP, Testa D, Galli V, Macchi V, De Caro R: Parapharyngeal ectopic thyroid: the possible persistence of the lateral thyroid anlage. Clinical case report. Surg Radiol Anat 2004, 26(4):338-343.

9. Cooper DS, Doherty GM, Haugen BR, Kloos RT, Lee SL, Mandel SJ, Mazzaferri EL, Mclver B, Pacini F, Schlumberger M, et al: Revised American Thyroid Association management guidelines for patients with thyroid nodules and differentiated thyroid cancer. Thyroid 2009, 19(11):1167-1214.

10. Vitale M: SEREX: a promising approach for identification of thyroid cancer serological biomarkers. Clin Endocrinol (Oxf) 2013.

11. Lodola F, Laforenza U, Bonetti E, Lim D, Dragoni S, Bottino C, Ong HL, Guerra G, Ganini C, Massa M, et al: Store-operated Ca2+ entry is remodelled and controls in vitro angiogenesis in endothelial progenitor cells isolated from tumoral patients. PLOS One 2012, 7(9):e42541.

12. Moccia F, Bonetti E, Dragoni S, Fontana J, Lodola F, Berra Romani R, Laforenza U, Rosti $V$, Tanzi F: Hematopoietic progenitor and stem cells circulate by surfing on intracellular Ca2+ waves: A novel target for cell-based therapy and anticancer treatment? Curr Signal Transd T 2012, 7(7):161-176.

13. Moccia F, Dragoni S, Lodola F, Bonetti E, Bottino C, Guerra G, Laforenza U, Rosti V, Tanzi F: Store-dependent $\mathrm{Ca}(2+)$ entry in endothelial progenitor cells as a perspective tool to enhance cell-based therapy and adverse tumour vascularization. Curr Med Chem 2012, 19(34):5802-5818.

14. Dragoni S, Laforenza U, Bonetti E, Lodola F, Bottino C, Guerra G, Borghesi A Stronati M, Rosti V, Tanzi F, Moccia F: Canonical Transient Receptor Potential 3 channel triggers VEGF-induced intracellular ca2+ oscillations in endothelial progenitor cells isolated from umbilical cord blood. Stem Cells and Development 2013, 22(19):2561-2580.

15. Dragoni S, Laforenza U, Bonetti E, Lodola F, Bottino C, Berra-Romani R, Carlo Bongio G, Cinelli MP, Guerra G, Pedrazzoli P, et al: Vascular endothelial growth factor stimulates endothelial colony forming cells proliferation and tubulogenesis by inducing oscillations in intracellular Ca2+ concentration. Stem Cells 2011, 29(11):1898-1907.

16. Sanchez-Hernandez $Y$, Laforenza U, Bonetti E, Fontana J, Dragoni S, Russo M, Avelino-Cruz JE, Schinelli S, Testa D, Guerra G, et al: Storeoperated $\mathrm{Ca}(2+)$ entry is expressed in human endothelial progenitor cells. Stem Cells Dev 2010, 19(12):1967-1981.

17. Monteith GR, MCAndrew D, Faddy HM, Roberts-Thomson SJ: Calcium and cancer: targeting Ca2+ transport. Nat Rev Cancer 2007, 7(7):519-530.

18. Ouadid-Ahidouch $H$, Dhennin-Duthille I, Gautier M, Sevestre $H$, Ahidouch A: TRP channels: diagnostic markers and therapeutic targets for breast cancer? Trends Mol Med 2013, 19(2):117-124.

19. Bellevicine C, Cozzolino I, Malapelle U, Zeppa P, Troncone G: Cytological and molecular features of papillary thyroid carcinoma with prominent hobnail features: a case report. Acta Cytol 2012, 56(5):560-564.

20. Vitale M: Intratumor BRAF(V600E) Heterogeneity and Kinase Inhibitors in the Treatment of Thyroid Cancer: A Call for Participation. Thyroid 2013, 23(4):517-519.

21. Kim Ml, Alexander EK: Diagnostic use of molecular markers in the evaluation of thyroid nodules. Endocr Pract 2012, 18(5):796-802.

22. Marotta V, Guerra A, Zatelli MC, Uberti ED, Di Stasi V, Faggiano A, Colao A, Vitale M: BRAF mutation positive papillary thyroid carcinoma is less advanced when Hashimoto's thyroiditis lymphocytic infiltration is present. Clin Endocrinol (Oxf).

23. Guerra A, Marotta V, Deandrea M, Motta M, Limone PP, Caleo A, Zeppa P, Esposito S, Fulciniti F, Vitale M: BRAF (V600E) associates with cytoplasmatic localization of p27kip1 and higher cytokeratin 19 expression in papillary thyroid carcinoma. Endocrine 2012

24. Petruzziello F, Zeppa P, Ciancia G, Cozzolino I, Fernandez LS, Cervasio M, Musto P, D'Auria F, Vita G, Morabito F, et al: Cytological and histological detection of amyloid deposits in bone marrow of patients affected by multiple myeloma. Leuk Lymphoma 2011, 52(12):2304-2307.

25. Zeppa P, Varone V, Cozzolino I, Salvatore D, Vetrani A, Palombini L: Fine needle cytology and flow cytometry of ectopic cervical thymoma: a case report. Acta Cytol 2010, 54(5 Suppl):998-1002. 
26. Alexander EK, Kennedy GC, Baloch ZW, Cibas ES, Chudova D, Diggans J, Friedman L, Kloos RT, LiVolsi VA, Mandel SJ, et al: Preoperative diagnosis of benign thyroid nodules with indeterminate cytology. N Engl J Med 2012, 367(8):705-715.

27. Hodak SP, Rosenthal DS: Information for clinicians: commercially available molecular diagnosis testing in the evaluation of thyroid nodule fineneedle aspiration specimens. Thyroid 2013, 23(2):131-134.

28. Guerra A, Di Stasi V, Zeppa P, Faggiano A, Marotta V, Vitale M: BRAFV600E assessment by pyrosequencing in fine needle aspirates of thyroid nodules with concurrent Hashimoto's thyroiditis is a reliable assay. Endocrine 2013.

29. Cozzolino I, Scognamiglio G, Sosa Fernandez LV, Zeppa P: Lymph nodes fine needle cytology in the diagnosis of infectious diseases: cytological and histological correlations. Infez Med 2012, 20(Suppl 3):16-20.

30. Bellevicine C, Malapelle U, laccarino A, Schettino P, Napolitano V, Zeppa P, Troncone G: Foamy gland pancreatic ductal adenocarcinoma diagnosed on EUS-FNA: a histochemical, immunohistochemical, and molecular report. Diagn Cytopathol 2013, 41(1):77-80.

31. Zeppa P, Cozzolino I, Peluso AL, Troncone G, Lucariello A, Picardi M, Carella C, Pane F, Vetrani A, Palombini L: Cytologic, flow cytometry, and molecular assessment of lymphoid infiltrate in fine-needle cytology samples of Hashimoto thyroiditis. Cancer 2009, 117(3):174-184.

32. Cozzolino I, Nappa S, Picardi M, De Renzo A, Troncone G, Palombini L, Zeppa $\mathrm{P}$ : Clonal B-cell population in a reactive lymph node in acquired immunodeficiency syndrome. Diagn Cytopathol 2009, 37(12):910-914

33. Gervasi R, Orlando G, Lerose MA, Amato B, Docimo G, Zeppa P, Puzziello A: Thyroid surgery in geriatric patients: a literature review. BMC Surg 2012, 12(Suppl 1):S16.

34. Zeppa P, Barra E, Napolitano V, Cozzolino I, Troncone G, Picardi M, De Renzo A, Mainenti PP, Vetrani A, Palombini L: Impact of endoscopic ultrasound-guided fine needle aspiration (EUS-FNA) in lymph nodal and mediastinal lesions: a multicenter experience. Diagn Cytopathol 2010, 39(10):723-729.

35. D'Antonio A, Baldi C, Memoli D, Caleo A, Rosamilio R, Zeppa P: Fine needle aspiration biopsy of intraparotid spindle cell lipoma: a case report. Diagn Cytopathol 2013, 41(2):171-173.

36. D'Antonio A, Paolella G, Zeppa P: Rapidly growing intraparotid mass in a young child. J Craniofac Surg 2012, 23(4):e305-306.

37. Cipullo C, Amato B, Vigliar E, Di Crescenzo V, Zeppa P: Lymph node fine needle cytology in the diagnosis of infectious diseases and reactive unspecific processes. Infez Med 2012, 20(Suppl 3):30-33.

38. Sosa Fernandez LV, Plaitano F, Varone V, Cozzolino I: Lymph node fine needle cytology in the diagnosis of infectious diseases and ancillary techniques. Infez Med 2012, 20(Suppl 3):21-25.

39. Cozzolino I, Vigliar E, Sosa Fernandez LV, Selleri C, Pepe S, Vitale M, Triggiani M, Zeppa P: Non lymphomatous clonal B-Cell populations in enlarged lymph nodes in acquired immunodeficiency syndrome. Infez Med 2012, 20(Suppl 2):35-42.

40. Ansell SM, Grant CS, Habermann TM: Primary thyroid lymphoma. Semin Oncol 1999, 26(3):316-323.

41. Pedersen RK, Pedersen NT: Primary non-Hodgkin's lymphoma of the thyroid gland: a population based study. Histopathology 1996, 28(1):25-32.

42. Singer JA: Primary lymphoma of the thyroid. Am Surg 1998, 64(4):334-337.

43. Kini SR: Thyroid Cytopathology: A Text and Atlas. Lippincott Williams \& Wilkins 2008.

44. Sapio MR, Guerra A, Marotta V, Campanile E, Formisano R, Deandrea M, Motta M, Limone PP, Fenzi G, Rossi G, et al: High growth rate of benign thyroid nodules bearing RET/PTC rearrangements. J Clin Endocrinol Metab 2011, 96(6):E916-919.

45. Marotta V, Guerra A, Sapio MR, Vitale M: RET/PTC rearrangement in benign and malignant thyroid diseases: a clinical standpoint. Eur J Endocrinol 2011, 165(4):499-507.

46. Matsuzuka F, Miyauchi A, Katayama S, Narabayashi I, Ikeda H, Kuma K, Sugawara M: Clinical aspects of primary thyroid lymphoma: diagnosis and treatment based on our experience of 119 cases. Thyroid 1993, 3(2):93-99.

47. Skarsgard ED, Connors JM, Robins RE: A current analysis of primary lymphoma of the thyroid. Arch Surg 1991, 126(10):1199-1203, discussion 1203-1194.
48. Klyachkin ML, Schwartz RW, Cibull M, Munn RK, Regine WF, Kenady DE, McGrath PC, Sloan DA: Thyroid lymphoma: is there a role for surgery? Am Surg 1998, 64(3):234-238.

49. Anderson L, Middleton WD, Teefey SA, Reading CC, Langer JE, Desser T, Szabunio MM, Hildebolt CF, Mandel SJ, Cronan JJ: Hashimoto thyroiditis: Part 1, sonographic analysis of the nodular form of Hashimoto thyroiditis. AJR Am J Roentgenol 195(1):208-215.

50. Anderson L, Middleton WD, Teefey SA, Reading CC, Langer JE, Desser T, Szabunio MM, Mandel SJ, Hildebolt CF, Cronan JJ: Hashimoto thyroiditis: Part 2, sonographic analysis of benign and malignant nodules in patients with diffuse Hashimoto thyroiditis. AJR Am J Roentgenol 195(1):216-222.

doi:10.1186/1471-2482-13-S2-S49

Cite this article as: Vigliar et al:: Early cytological diagnosis of extranodal stage I, primary thyroid Non-Hodgkin lymphoma in elderly patients. Report of two cases and review of the literature. BMC Surgery 201313 (Suppl 2):S49.

\section{Submit your next manuscript to BioMed Central and take full advantage of:}

- Convenient online submission

- Thorough peer review

- No space constraints or color figure charges

- Immediate publication on acceptance

- Inclusion in PubMed, CAS, Scopus and Google Scholar

- Research which is freely available for redistribution

Submit your manuscript at www.biomedcentral.com/submit
Biomed Central 